Acta vet. scand. $1973,14,745-757$.

From the Department of Clinical Biochemistry and the Department of Clinical Radiology, Royal Veterinary College, Stockholm, Sweden.

\title{
PERIPHERAL PLASMA LEVELS OF CORTICOSTEROIDS IN NORMAL BEAGLES AND GREYHOUNDS MEASURED BY A RAPID COMPETITIVE PROTEIN BINDING TECHNIQUE*
}

\author{
By \\ M. Richkind ${ }^{\star \star}$ and L.-E. Edqvist
}

RICHKIND, M. and L.-E. EDQVIST: Peripheral plasma levels of corticosteroids in normal Beagles and Greyhounds measured by a rapid competitive protein binding technique. Acta vet. scand. 1973, 14, 745-757. - A rapid competitive protein binding method for the measurement of peripheral plasma levels of corticosteroids in dogs was evaluated and applied. The rapid method was found to give a minor overestimation of the cortisol levels as compared to the method including purification of the plasma extract on Sephadex LH-20 columns. In Beagles and Greyhounds mean peripheral plasma levels of corticosteroids of 25.4 and $18.0 \mathrm{ng} / \mathrm{ml}$ were found respectively. No diurnal variation of peripheral plasma levels of corticosteroids was obtained. After the intravenous administration of dexamethasone peripheral plasma levels of corticosteroids were found to decrease to about $20 \%$ of the pretreatment levels. When ACTH was administered i.m. a nearly 10 fold increase of the corticosteroid levels was found 60 to $90 \mathrm{~min}$. after the injections. The rapid method described and evaluated should be of value for diagnosis of adrenal syndrome in the dog.

dogs; plasma levels; cortisol; corticosterone;

A C T H; dexamethas one.

Colorimetric and fluorometric techniques have been used for the determination of peripheral plasma levels of corticosteroids in the dog (Wilson et al. 1967; Rijnberk et al. 1968; Breznock \& McQueen 1969; McManus et al. 1970; Halliwell et al. 1971; Willeberg \& Krogsgaard 1972). These techniques are generally time-consuming, elaborate and require relatively large volumes of plasma.

- This investigation was supported by the John M. Olin Foundation.

* Present address: Department of Radiology, Nuclear Medicine Division, Center for the Health Sciences, University of California, Los Angeles, USA. 
The introduction and development of a competitive protein binding technique for the measurement of peripheral plasma levels of cortisol * and other steroids made it possible to assay cortisol in small amounts of plasma (Murphy 1964, 1967).

The purpose of the present investigation was to evaluate and apply a rapid competitive protein binding technique for the measurement of peripheral plasma levels of cortisol in the dog.

\section{MATERIALS AND METHODS}

Six healthy Greyhounds ( 3 males and 3 females, aged 10 months) and 38 Beagles (17 males and 21 females, aged between 10 and 48 months) were used. Blood samples were obtained through puncture of the cephalic vein. The blood was collected into heparinized tubes. After centrifugation, plasma was removed and stored at below $-20^{\circ} \mathrm{C}$ until assayed. In order to evaluate a possible diurnal variation of cortisol secretion, blood samples were taken from the Greyhounds on 3 consecutive days every 8 hrs. The Beagles were sampled randomly.

Dexamethasone-21-phosphate (Merck \& Co. Inc. Rahway, New Jersey, USA) was given i.v. at a dose of $0.01 \mathrm{mg} / \mathrm{kg}$ body weight, and 2 i.u. of ACTH gel (Ferring AB, Malmö, Sweden) per kg body weight was administered i.m. to the 6 Grcyhounds. Blood samples were obtained prior to administration and thereafter every $30 \mathrm{~min}$. for $4 \mathrm{hrs}$.

Plasma pools were made from normal dogs (Pool I), from dexamethasone treated dogs (Pool II) and from ACTH stimulated dogs (Pool III).

* The following abbreviations and trivial names are used:

ACTH: adrenocorticotrophic hormone.

Aldosterone: 11ß,21-dihydroxy-4-pregnene-3,18,20-trione.

$\mathrm{B}^{3} \mathrm{H}$ : corticosterone-1,2-3 $\mathrm{H}$.

CBG: corticosteroid binding globulin.

CBG-B ${ }^{3} \mathrm{H}$ : protein binding solution.

Corticosterone: 11 $\beta, 21$-dihydroxy-4-pregnene-3,20-dione.

Cortisol: $11 \beta, 17 \alpha, 21$-trihydroxy-4-pregnene-3,20-dione.

Deoxycorticosterone: 21-hydroxy-4-pregnene-3,20-dione.

11-deoxycortisol: $17 \alpha, 21$-dihydroxy-4-pregnene-3,20-dione.

17 $\beta$-estradiol: $1,3,5(10)$-estratriene-3,17 $\beta$-diol.

$17 \alpha$-hydroxyprogesterone: $17 \alpha$-hydroxy-4-pregnene-3,20-dione.

$\mathrm{n}$ : number of observations.

Progesterone: 4-pregnene-3,20-dione.

s: standard deviation.

S.A.: specific activity.

s.e.m.: standard error of the mean.

Testosterone: 17 $\beta$-hydroxy-4-androsten-3-one. 
Cortisol-1,2- ${ }^{3} \mathrm{H}$ (S.A. $44 \mathrm{Ci} / \mathrm{mmol}$ ), corticosterone-1,2-3 $\mathrm{H}$ (S.A. 44 $\mathrm{Ci} / \mathrm{mmol}$ ) 11-deoxycortisol-1,2- ${ }^{3} \mathrm{H}$ (S.A. $25 \mathrm{Ci} / \mathrm{mmol}$ ), deoxycorticosterone-1,2- ${ }^{3} \mathrm{H}$ (S.A. $25 \mathrm{Ci} / \mathrm{mmol}$ ), aldosterone-1,2- ${ }^{3} \mathrm{H}$ (S.A. $41 \mathrm{Ci} / \mathrm{mmol}$ ), progesterone-7-3 $\mathrm{H}$ (S.A. $20 \mathrm{Ci} / \mathrm{mmol}$ ), $17 \alpha$-hydroxyprogesterone-1, ${ }^{-3} \mathrm{H}$ (S.A. $49 \mathrm{Ci} / \mathrm{mmol}$ ), $20 \alpha$-hydroxy-4-pregnene-3-one-1,2-3 $\mathrm{H}$ (S.A. $33 \mathrm{Ci} /$ mmol), 17ß-estradiol-6,7- ${ }^{3} \mathrm{H}$ (S.A. $44 \mathrm{Ci} / \mathrm{mmol}$ ) and testosterone-1,2-3 $\mathrm{H}$ (S.A. $43 \mathrm{Ci} / \mathrm{mmol}$ ) were obtained from NEN Chemicals GmBH, Germany. Cortisol was purchased from Sigma Chemical Co., St. Louis, Missouri, USA, and stored in redistilled ethanol $(10 \mathrm{ng} / \mathrm{ml})$ at below $-20^{\circ} \mathrm{C}$. Dichlormethane and methanol were obtained from Merck and Co., Germany. All solvents used were of reagent grade and were not further purified unless otherwise stated. Florisil 60-100 mesh (Sigma Chemical Co., St. Louis, Missouri, USA) was washed repeatedly with glass distilled water, and the finer particles were decanted. The remaining particles were dried at $120^{\circ} \mathrm{C}$ overnight and subsequently stored in an exsiccator. Plasma containing the binding protein (CBG) was obtained from women on oral combined contraceptive pills. The plasma was stored in $1 \mathrm{ml}$ aliquots at below $-20^{\circ} \mathrm{C}$.

Preparation of the protein binding solution ( $\left.C B G-B^{3} H\right) .41 .2 \mathrm{ng}$ of a stock benzene/ethanol $(9: 1)$ corticosterone-1,2-3 $\mathrm{H}$ solution was placed in a glass flask and evaporated to dryness. Thereafter $100 \mathrm{ml}$ of glass distilled water was added together with $120 \mu \mathrm{l}$ of the binding protein. The $\mathrm{CBG}-\mathrm{B}^{3} \mathrm{H}$ solution was genily shaken and stored in a refrigerator at $5^{\circ} \mathrm{C}$ for $1 \mathrm{hr}$. before use.

Preparation of the liquid-gel chromatography. Glass columns sized $300 \times 5 \mathrm{~mm}$ with teflon stop-cocks were prepared with a slurry of $2 \mathrm{~g}$ of Sephadex LH-20 (Pharmacia AB, Uppsala, Sweden). Before application to the column the Sephadex had swelled overnight in the solvent dichlormethane/methanol $(98: 2)$. Elution of the column was done by gravity flow.

Extraction. Plasma $(10-250 \mu \mathrm{l})$ was pipetted into duplicate test tubes containing $\sim 0.01 \mu \mathrm{Ci}$ of cortisol-1,2-3 $\mathrm{H}$ and extracted once with 20 vol. of dichlormethane on a Voriex mixer for $1 \mathrm{~min}$. Thereafter the tubes were centrifuged at below $-20^{\circ} \mathrm{C}$ for $10 \mathrm{~min}$. In order to obtain a clear separation of the plasma and the organic phase, the tubes were kept in a solution of acetone and dry ice ( solid $\mathrm{CO}_{2}$ ) after the centrifugation. The solvent was then transferred to tubes and evaporated to dryness under a stream of air in a $45^{\circ} \mathrm{C}$ water bath.

Liquid gel-chromatography. The evaporated plasma extract was redissolved in 6 successive 100 and $200 \mu \mathrm{l}$ portions of the column solvent (dichlormethane/methanol 98:2) and applied on the top of the gel-bed. When the sample had entered the gel-bed, column solvent was carefully added. The level was kept constant during the separation, providing a constant gravity flow of about $6-8 \mathrm{ml}$ per hr. Standardization of the columns was carried out using labelled steroids. The cortisol fractions were collected on a time basis. For further details of the liquid-gel chromatography, see Murphy (1971). The collected cortisol fractions were divided equally into 2 parts and evaporated to 
dryness. One part was assayed by competitive protein binding, while the other was used to determine the procedural losses. In order to evaluate a rapid method for the measurement of peripheral plasma corticosteroids, the column chromatography step was omitted. Extraction of the samples was carried out as described previously. However, the internal standardization procedure was not used in the rapid method.

Preparation of the standard curve. $0,0.5,1.0,2.0,4.0$ and $5.0 \mathrm{ng}$ of cortisol in ethanol $(10 \mathrm{ng} / \mathrm{ml})$ were pipetted into duplicate tubes. The tubes were evaporated to dryness. In order to correct for the reagent blank, column effluent equal in volume to the cortisol fraction was added to each point of the standard curve. For the rapid technique, the extraction solvent used was added to each point of the standard curve. The protein binding step was done in the same manner for both the complete and the rapid procedure. After evaporation of the solvent, $1 \mathrm{ml}$ of $\mathrm{CBG}-\mathrm{B}^{3} \mathrm{H}$ was added to each tube. The tubes were gently shaken and placed in a $45^{\circ} \mathrm{C}$ water bath for 5 min. Thereafter the tubes were placed in an ice bath for $10 \mathrm{~min}$. The unbound steroids were removed by shaking with $80 \mathrm{mg}$ of Florisil for $30 \mathrm{sec}$. From the supernatant $0.5 \mathrm{ml}$ was removed and transferred to liquid scintillation vials containing $15 \mathrm{ml}$ of scintillation solution $(100 \mathrm{~g}$ naphtalene, $7.0 \mathrm{~g}$ 2,5-diphenyloxazole and $0.3 \mathrm{~g}$ 1,4-bis,2(5-phenyl-oxazolyl)-benzene per l of dioxan). Each sample was counted in a liquid scintillation counter (Nuclear-Chicago Mark I) for $10 \mathrm{~min}$. The cortisol content of the experimental samples was extrapolated from the standard curves, corrected for procedural losses, and expressed in ng cortisol per $\mathrm{ml}$ of plasma.

Sensitivity. The sensitivity of the assay is dependent on the protein binding system, the plasma blank, the reagent blank, and the recovery. It was found that $0.06 \mathrm{ng}$ of cortisol was almost significantly different from zero $(P<0.05)$. The amount of dichlormethane used for the extraction was found to give a minor interference in the protein binding system. For example $10 \mathrm{ml}$ of dichlormethane, when processed by the rapid method, was found to be equivalent to about $0.3 \mathrm{ng}$ of cortisol as read off the standard curve. A similar blank $0.01 \mathrm{ng}$ as read off the standard curve was also obtained after the column separation procedure, since the column effluent mainly consisted of diclormethane. As previously mentioned these blanks were corrected for by adding equal amounts of the solvents to each point of the standard curves. In order to evaluate the plasma blank, 10 and $50 \mu$ of charcoal adsorbed dog plasma were assayed with the rapid procedure. The values obtained were found not to differ f 1 om zero. In this paper values below $0.1 \mathrm{ng}$ as read off the standard curve were considered to be below the practical detection limit of both the rapid procedure and the procedure including column chromatography.

Specificity. The specificity of the assay is dependent on the extraction properties of the solvent used, the protein binding system, and the physiological status of the animal investigated. The solvent $(20 \mathrm{vol}$. 
Table 1. Recovery percentage of various labelled steroids added to charcoal treated canine plasma and extracted once with 20 vol. of dichlormethane.

\begin{tabular}{|c|c|c|c|c|}
\hline $\begin{array}{l}\text { Steroids } \\
\text { added }\end{array}$ & $\mathbf{n}$ & $\begin{array}{c}\text { Recovery } \\
\%\end{array}$ & $\mathbf{s}$ & $\begin{array}{c}\text { Coefficient } \\
\text { of variation, } \%\end{array}$ \\
\hline Cortisol-1,2-3 $\mathrm{H}$ & 31 & 89.3 & 1.94 & 2.7 \\
\hline Corticosterone-1,2-3 $\mathrm{H}$ & 8 & 86.4 & 3.41 & 4.0 \\
\hline 11-deoxycortisol-1,2-3H & 8 & 62.8 & 2.18 & 3.5 \\
\hline Deoxycorticosterone-1,2-3H & 8 & 67.7 & 3.03 & 4.5 \\
\hline Aldosterone-1,2-3 $\mathrm{H}$ & 8 & 83.4 & 1.48 & 1.8 \\
\hline Progesterone-7-3 $\mathrm{H}$ & 12 & 48.5 & 2.01 & 4.1 \\
\hline $17 \alpha$-hydroxyprogesterone- $1,2-{ }^{3} \mathrm{H}$ & 10 & 86.6 & 1.57 & 1.8 \\
\hline $20 \alpha$-hydroxy-4-pregnene-3-one-1,2-3 $\mathrm{H}$ & 9 & 78.9 & 2.65 & 3.4 \\
\hline $17 \beta$-estradiol-6,7-3 $\mathrm{H}$ & 9 & 97.2 & 1.82 & 1.9 \\
\hline Testosterone-1,2-3 $\mathrm{H}$ & 9 & 84.9 & 1.75 & 2.1 \\
\hline
\end{tabular}

dichlormethane) was found to extract other steroids than corticosteroids with high affinity for the CBG (Table 1). In order to control the specificity of the rapid method, a column separation system was used. The column system used (Murphy 1971) was found to separate cortisol from other interfering steroids. When using the column separation system an internal standard was applied in order to control the recovery of each sample processed. The recovery of added labelled cortisol was $79.9 \%(\mathrm{~s}=4.2 ; \mathrm{n}=25)$, and was independent of the plasma volume extracted $(50$ and $250 \mu \mathrm{l})$ and the amount of cortisol measured $(2-110 \mathrm{ng} / \mathrm{ml})$.

Three plasma pools containing different amounts of cortisol were processed using both the rapid procedure and the procedure including column gel chromatography. The results of the measurements are given in Table 2. As expected, the rapid procedure was found to give higher values for cortisol as compared to the values obtained after chromatography of the plasma extract. This overestimation is mainly due to interference from other corticosteroids than cortisol. Therefore the results obtained with the

T a b l e 2. Comparison of values obtained after measurement of 3 different plasma pools, using the competitive protein binding technique with and without prior purification of the plasma extract.

\begin{tabular}{|c|c|c|c|c|c|c|c|c|}
\hline & \multicolumn{4}{|c|}{ Without purification } & \multicolumn{4}{|c|}{ With purification } \\
\hline & $\mathbf{n}$ & $\overline{\mathbf{x}}$ & $\mathbf{s}$ & $\begin{array}{r}\text { coefficient of } \\
\text { variation, } \%\end{array}$ & $\mathbf{n}$ & $\overline{\mathbf{x}}$ & $\mathbf{s}$ & $\begin{array}{l}\text { coefficient of } \\
\text { variation, \% }\end{array}$ \\
\hline Pool I & 10 & 24.0 & 2.5 & 10.4 & 5 & 20.3 & 1.0 & 4.4 \\
\hline Pool II & 10 & 5.1 & 0.9 & 17.7 & 5 & 2.2 & 0.4 & 3.9 \\
\hline Pool III & 10 & 191.8 & 22.0 & 11.5 & 5 & 111.5 & 5.5 & 5.0 \\
\hline
\end{tabular}


T a b l e 3. Recovery of crystalline cortisol added to dexamethasone treated or charcoal adsorbed canine plasma. Endogenous corticosteroid levels are subtracted and the values are corrected for procedural losses.

\begin{tabular}{lcccc}
\hline $\begin{array}{l}\text { Cortisol } \\
\text { added (ng) }\end{array}$ & $\begin{array}{c}\text { Cortisol } \\
\text { measured (ng) }\end{array}$ & $\mathrm{n}$ & $\mathrm{s}$ & $\begin{array}{c}\text { Coefficient of } \\
\text { variation, \% }\end{array}$ \\
\hline \multicolumn{2}{l}{ Extraction } & solvent: Dichlormethane & & \\
0.50 & 0.48 & 9 & 0.01 & 3.0 \\
1.0 & 0.97 & 10 & 0.10 & 9.8 \\
2.0 & 2.00 & 8 & 0.13 & 6.5 \\
4.0 & 3.87 & 12 & 0.32 & 8.3 \\
5.0 & 4.91 & 7 & 0.15 & 3.0 \\
Extraction & solvent: Methanol & & & \\
0.50 & 0.53 & 50 & 0.12 & 25.3 \\
1.0 & 1.28 & 40 & 0.22 & 14.4 \\
2.0 & 2.89 & 38 & 0.40 & 15.6 \\
4.0 & 6.76 & 39 & 0.83 & 13.7 \\
5.0 & 7.99 & 15 & 1.05 & 14.6 \\
\hline
\end{tabular}

rapid procedure were given as corticosteroids instead of cortisol. It must be recalled that none of the dogs used in the present investigation were in the luteal phase of the sexual cycle. The progesterone interference obtained during the luteal phase can be avoided by prewashing the plasma samples with petroleum ether.

Accuracy. The accuracy was tested by adding different amounts of crystalline cortisol $(0.0,0.5,1.0,2.0,4.0$ and $5.0 \mathrm{ng})$ to charcoal adsorbed dog plasma (10 and $50 \mu \mathrm{l}$ ). The samples were extracted with dichlormethane and processed with the rapid procedure. The values were corrected for procedural losses (Table 3 ). When using 10 vol. of ethanol for the extraction instead of dichlormethane, an unexplainable bad accuracy was obtained for concentrations of added cortisol exceeding $1.0 \mathrm{ng}$ (Table 3 ).

Precision. The precision and the recovery for the extraction step using 10 and $50 \mu \mathrm{l}$ of plasma are given in Table 3 . The precision of the method was calculated from duplicate plasma samples (Table 4).

T a ble 4. The precision for the measurement of peripheral plasma levels of corticosteroids in dogs.

\begin{tabular}{rrccc}
\hline $\begin{array}{l}\text { Range } \\
\text { ng/ml }\end{array}$ & $\overline{\mathrm{x}}$ & $\mathrm{s}$ & $\begin{array}{c}\text { Coefficient of } \\
\text { variation, } \%\end{array}$ & $\begin{array}{c}\text { Number of } \\
\text { duplicate } \\
\text { estimations }\end{array}$ \\
\hline $2.0-20.9$ & 12.4 & 1.1 & 8.9 & 35 \\
$21.0-80.9$ & 38.0 & 6.0 & 15.0 & 34 \\
$81.0-500$ & 249.0 & 7.0 & 2.8 & 24 \\
\hline
\end{tabular}




\section{RESULTS}

The mean peripheral plasma level of corticosteroids in Greyhounds was $18.0 \mathrm{ng} / \mathrm{ml}$ (Table 5). No significant differences were found between male and female dogs, 16.3 and $19.6 \mathrm{ng} / \mathrm{ml}$ respectively (Table 5 ). No significant diurnal variation was found between blood samples obtained at 8 a.m., 3 p.m. or 12 p.m. for 3 consecutive days. The mean values obtained were $18.9,18.5$ and $16.6 \mathrm{ng} / \mathrm{ml}$ respectively (Table 5 ). For the Beagles the mean peripheral plasma levels of corticosteroids obtained were $25.4 \mathrm{ng} /$ ml (Table 5). No significant difference was found between males and females, 23.2 and $27.7 \mathrm{ng} / \mathrm{ml}$ respectively. No significant difference was obtained when comparing the levels obtained in Greyhounds and in Beagles. The mean peripheral plasma level of corticosteroids for both breeds was $22.1 \mathrm{ng} / \mathrm{ml}$ (Table 5).

The levels of the plasma pools were measured by both the rapid procedure and the procedure including purification of the plasma extract. The results of the measurements are given in Table 2. It was found that the rapid competitive protein binding technique gave higher cortisol levels as compared to the technique including column gel chromatography. Pool I contained $24.0 \mathrm{ng} /$ $\mathrm{ml}(\mathrm{s}=2.5)$ as measured by the rapid technique and $20.3 \mathrm{ng} / \mathrm{ml}$ ( $\mathrm{s}=1.0$ ) using column gel chromatography. Pool II contained $5.1 \mathrm{ng} / \mathrm{ml}(\mathrm{s}=0.9)$ as measured by the rapid method and 2.2

T a ble 5. Peripheral plasma levels of cortisteroids in Beagles and Greyhounds.

\begin{tabular}{lccccc}
\hline $\begin{array}{l}\text { Breed } \\
\text { of dogs }\end{array}$ & $\begin{array}{c}\overline{\mathrm{x}} \\
(\mathrm{ng} / \mathrm{ml})\end{array}$ & $\mathrm{s}$ & $\begin{array}{c}\text { Coefficient of } \\
\text { variation, } \%\end{array}$ & $\begin{array}{c}\text { Number } \\
\text { of dogs }\end{array}$ & $\begin{array}{c}\text { Number of } \\
\text { samples }\end{array}$ \\
\hline B e a g l e s & & & & & \\
males & 23.2 & 16.9 & 72.8 & 17 & 46 \\
females & 27.7 & 13.5 & 48.7 & 21 & 34 \\
all Beagles & 25.4 & 15.4 & 60.6 & 38 & 80 \\
G r e y h o u n d s & & & & \\
males & 16.3 & 8.7 & 53.4 & 3 & 27 \\
females & 19.6 & 13.5 & 68.9 & 3 & 27 \\
8 a.m. & 18.9 & 14.4 & 76.2 & 6 & 18 \\
3 p.m. & 18.5 & 5.2 & 28.1 & 6 & 18 \\
12 p.m. & 16.6 & 12.9 & 77.1 & 6 & 18 \\
all Greyhounds & 18.0 & 11.4 & 63.3 & 6 & 54 \\
\hline All dogs & 22.1 & 14.2 & 64.3 & 44 & 134 \\
\hline
\end{tabular}




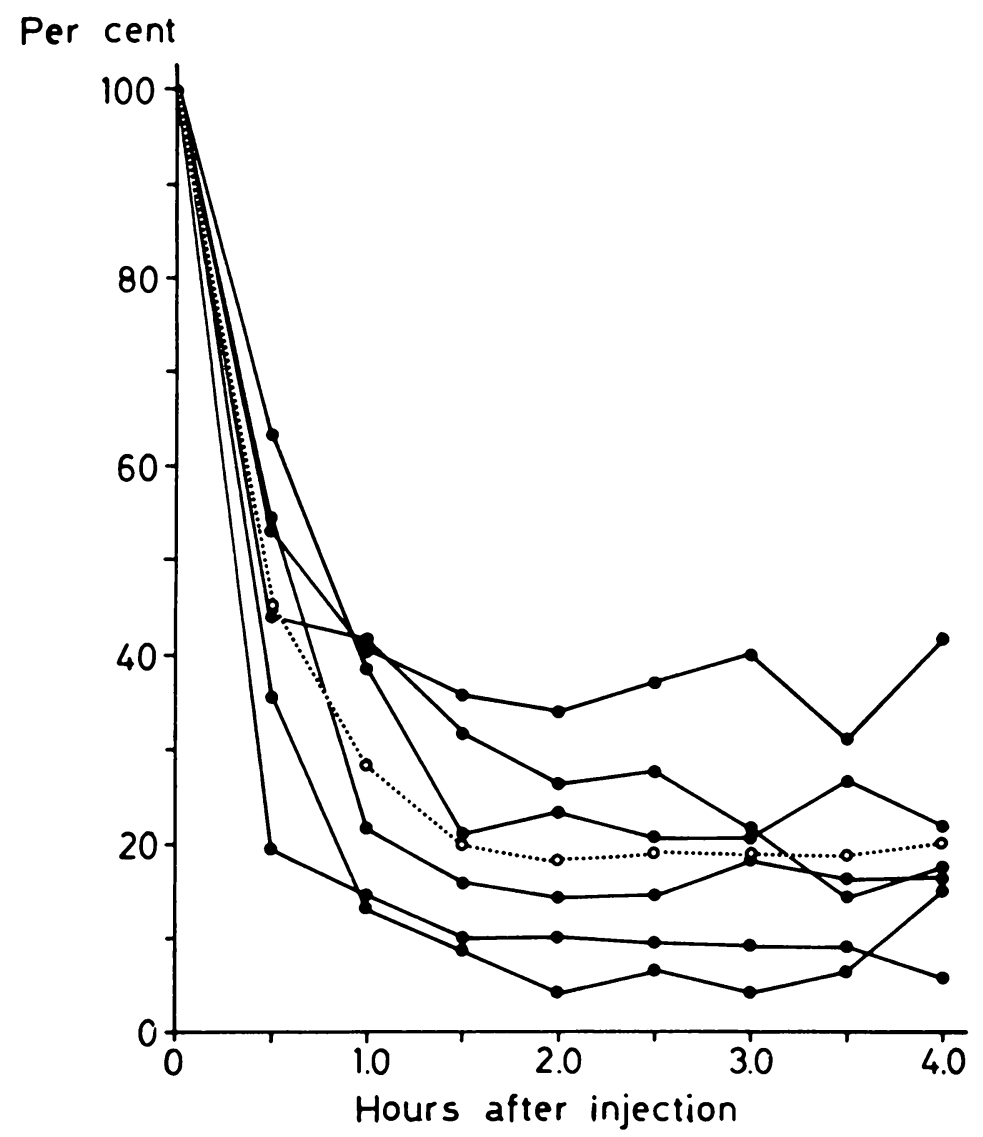

F i g u re 1. Peripheral plasma levels of corticosteroids in 6 dogs after i.v. injection of $0.01 \mathrm{mg}$ of dexamethasone per $\mathrm{kg}$ of body weight. Each individual level of corticosteroids obtained before treatment has arbitrarily been plotted as $100 \%$. Each point represents the mean of duplicate determinations. Dotted line indicates the mean concentration.

$\mathrm{ng} / \mathrm{ml}(\mathrm{s}=0.4)$ using column gel chromatography. Pool III contained $191.8 \mathrm{ng} / \mathrm{ml}(\mathrm{s}=22)$ as measured by the rapid method and $111.5 \mathrm{ng} / \mathrm{ml}(\mathrm{s}=5.5)$ using column gel chromatography (Table 2).

The result of the dexamethasone administration on the peripheral plasma levels of corticosteroids as measured by the rapid competitive protein binding technique in 6 Greyhounds is given in Fig. 1. Each individual value recorded before injection was arbitrarily calculated as $100 \%$. The mean pretreatment value was $24.4 \mathrm{ng} / \mathrm{ml}$ (s.e.m. $=0.7$ ). Thirty min. after the administra- 


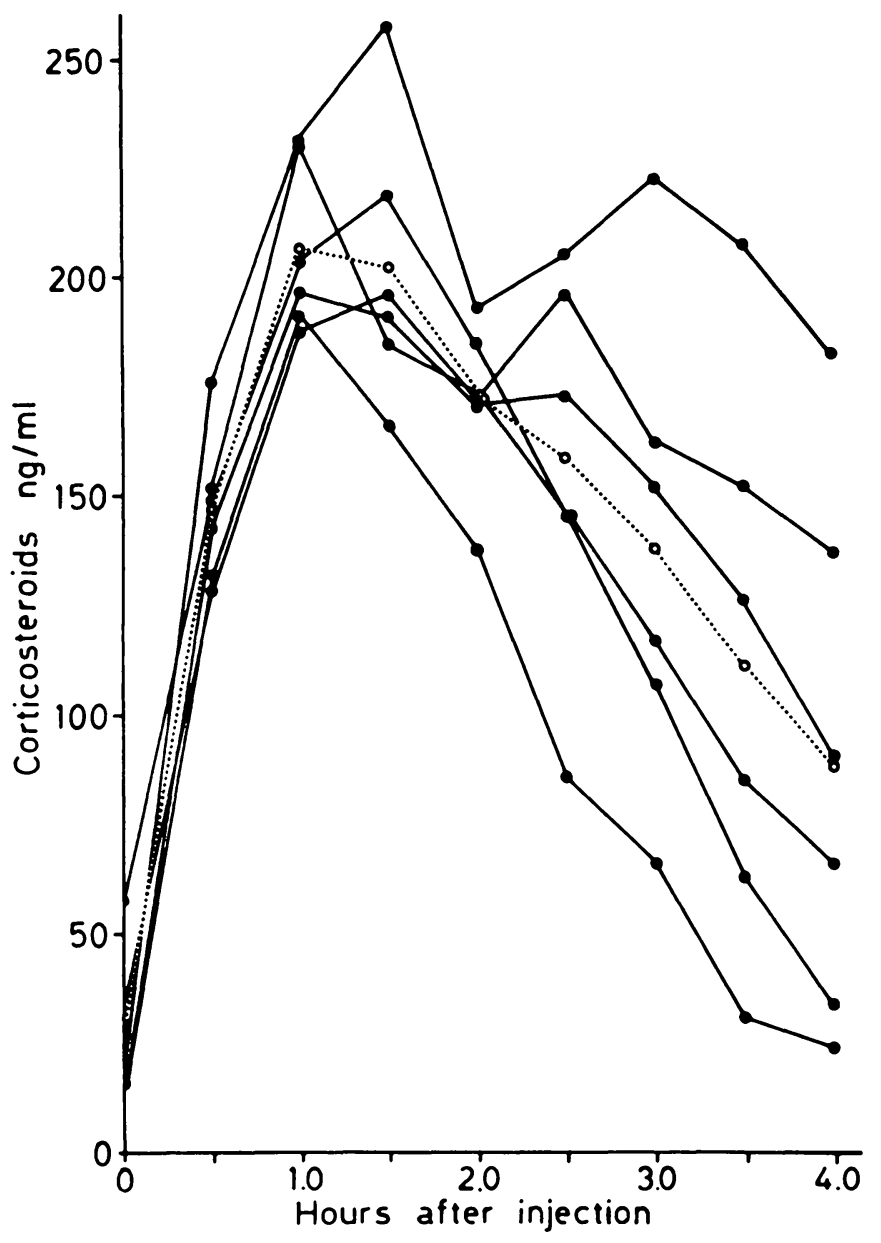

Figure 2. Peripheral plasma levels of corticosteroids in 6 dogs after i.m. injection of 2 i.u. of ACTH per $\mathrm{kg}$ of body weight. Each point represents the mean of duplicate determinations. Dotted line indicates the mean concentration.

tion the mean value recorded was $45.1 \%($ s.e.m. $=6.4)$ and after $1 \mathrm{hr}$. the mean value was $28.3 \%$ (s.e.m. $=5.5$ ). Between 1 and $4 \mathrm{hrs}$. after the injection of dexamethasone a constant level of about $20 \%$ of the preadministration value was obtained. The decrease was highly significant.

In the 6 Greyhounds given ACTH the mean peripheral plasma level of corticosteroids was $29.3 \mathrm{ng} / \mathrm{ml}($ s.e.m. $=6.5)$ before injection (Fig. 2). Mean levels of 148.5 (s.e.m. $=6.2$ ) and 206.9 
$($ s.e.m. $=7.9) \mathrm{ng} / \mathrm{ml}$ were obtained 30 and $60 \mathrm{~min}$. after injection. Thereafter the mean level declined slightly after $90 \mathrm{~min}$. to 202.7 (s.e.m. $=7.8) \mathrm{ng} / \mathrm{ml}$. Two and $4 \mathrm{hrs}$. after administration the mean level had decreased to 172.3 (s.e.m. $=7.8$ ) and 88.9 $($ s.e.m. $=25.2) \mathrm{ng} / \mathrm{ml}$ respectively. The increase obtained after the injection of ACTH was found to be highly significant.

\section{DISCUSSION}

The values obtained by the rapid competitive protein binding technique were compared to the values obtained using column chromatography for purification of the plasma extract. Slightly higher values were constantly obtained by the rapid competitive protein binding technique. This was due to interference by other steroids with affinity for CBG. These sieroids were extracted together with the cortisol from the plasma. However, the rapid method described and evaluated in the present paper is considered to give a satisfactory approximation of the cortisol level. For clinical purposes the method is quite sufficient. The results of the dexamethasone suppression and ACTH stimulation tests support this statement.

The specificity of the rapid method is dependent on the physiological status of the animal from which the blood samples are collected. The amount of cortisol in the dog seems to be high in comparison to the amount of other steroids with high affinity for CBG (Farrell et al. 1955; Carstensen et al. 1959; Heap et al. 1966; Holzbauer \& Newport 1969). It was previously shown that the effect of small amounts of interfering steroids in competitive protein binding techniques is less than expected from measurements made of each individual steroid (Johansson 1970).

When comparing the values obtained with the rapid technique to the values obtained after column chromatography, it can be concluded that about $85 \%$ of the plasma level of corticosteroids in the normal dog was due to cortisol. Steenburg \& Thomasson (1965) estimated the adrenal venous plasma corticosterone: cortisol ratio and found ratios varying between $0.15: 1$ and $0.54: 1$ Siegel \& Belshaw (1968) reported peripheral plasma levels of cortisol and corticosterone of $2-10 \mu \mathrm{g} / 100 \mathrm{ml}$ and $1-2 \mu \mathrm{g} / 100$ $\mathrm{ml}$ respectively.

Murphy (1967) found dexamethasone not to displace tritiated corticosterone from $\mathrm{CBG}$ and the present study provides further evidence. 
Halliwell et al. (1971) found a decrease of the peripheral plasma levels of cortisol of about $50 \%$ after the administration of dexamethasone. The present findings are in agreement with this observation (Fig. 1). Following the injection of ACTH a 3 to 4 fold increase of preadministration corticosteroid values was seen 60 to $90 \mathrm{~min}$. later. Halliwell et al. found maximum values $31 / 2$ hrs. after injection and Rijnberk et al. (1968) found the values to peak $5 \mathrm{hrs}$. after administration. This discrepancy is probably due to various ACTH preparations and dosage used. From the measurement of plasma pool II it was found that about $60 \%$ of the peripheral plasma level of corticosteroids as measured by the present technique was cortisol.

Rijnberk et al. reported the presence of a diurnal variation of peripheral plasma levels of corticosteroids in dogs. They obtained the highest values at 8 a.m. and the lowest values at 11 p.m. The daily variations found by Rijnberk et al. were less pronounced than the variations found in man. In the present investigation no diurnal variation was found. The absence of diurnal variation of peripheral plasma levels of corticosteroids was previously reported by Breznock \& McQueen (1969). Circulating plasma levels of corticosteroids might be increased due to a number of different stimules (Willet \& Erb 1972). Breznock \& McQueen found 3 to 4 times higher peripheral plasma levels of corticosteroids in 2 dogs which were apparently frightened during the experiment.

It can be concluded that nearly the same clinical information is obtained when using the rapid competitive protein binding procedure as compared to the complete procedure including purification on Sephadex LH-20 columns. Judging from the mean values of cortisol found in the normal dogs an estimate of the corticosteroid level on the basis of only 1 blood sample is of little clinical value. More complete and more detailed clinical information can obviously be obtained by applying the dexamethasone suppression and the ACTH stimulation tests. The rapid method described and evaluated in the paper should be of value for diagnosis of adrenal syndrome in the dog.

\section{REFERENCES}

Breznock, E. M.\& R. D. McQueen: Rapid fluorometric analysis of plasma corticosteroids as a test of adrenocortical function in the dog. Amer. J. vet. Res. 1969, 30, 1523-1533. 
Carstensen, H., G. W. Oertel \& K. B. Eik-Nes: Secretion of $17 \alpha$-hydroxy$\Delta^{5}$-pregnenolone by the canine adrenal gland during stimulation with adrenocorticotropin. J. biol. Chem. 1959, 234, 25702577.

Farrell, G. L., E. W. Rauschkolb \& P. C. Royce: Secretion of aldosterone by the adrenal of the dog. Effects of hypophysectomy and ACTH. Amer. J. Physiol. 1955, 182, 269-272.

Halliwell, R. E. W., R. M. Schwartzman, L. Hopkins \& D. McEvoy: The value of plasma corticosteroid assay in the diagnosis of Cushing's disease in the dog. J. small Anim. Pract. 1971, 12, 453462.

Heap, R. B., M. Holzbauer \& H. M. Newport: Adrenal secretion rates of C-19 and C-21 steroids before and after hypophysectomy in the pig and the dog. J. Endocr. 1966, 36, 159-176.

Holzbauer, M. \& H. M. Newport: Adrenal secretion and adrenal tissue concentrations of pregnenolone, progesterone, $11 \beta \mathrm{OH}$-androstenedione and some other steroids in young pigs and dogs. J. Physiol. (Lond.) 1969, 200, 821-848.

Johansson, E. D. B.: A simplified procedure for the assay of progesterone. Acta endocr. (Kbh.) 1970, Suppl. 147, 188-203.

McManus, J. L., G. B. Nimmons \& W. Buchta: Surgical and medical management of hyperadrenocorticalism in a Boston Terrier. Canad. vet. J. 1970, 11, 78-80.

Murphy, B. E. P.: Application of the property of protein-binding to the assay of minute quantities of hormones and other substances. Nature (Lond.) 1964, 201, 679-682.

Murphy, B. E. P.: Some studies of the protein-binding of steroids and their application of the routine micro and ultramicro measurement of various steroids in body fluids by competitive proteinbinding radioassay. J. clin. Endocr. 1967, 27, 973-990.

Murphy, B. E. P.: Sephadex column chromatography as an adjunct to competitive protein binding assays of steroids. Nature, New Biology 1971, 232, 21-24.

Rijnberk, A., P. J. der Kindern \& J. H. H. Thijssen: Investigations on the adrenocortical function of normal dogs. J. Endocr. 1968, 41, $387-395$.

Siegel, E. J. \& B. E. Belshaw: Laboratory evaluation of adrenocortical and thyroid functions in the dog. In Current Veterinary Therapy, III. R. W. Kirk, ed.; W. B. Saunders, Philadelphia, USA 1968, 545.

Steenburg, R. W. \& B. H. Thomasson: Dose response characteristics of methopirapone: studies in dogs utilizing a fluorescence procedure for estimating adrenal output of 11-hydroxycorticosteroids. Metabolism 1965, 14, 253-263.

Willeberg, P.\& O. W. Krogsgaard: Nogle tilfælde af Cushings syndrom hos hund. (Some cases of Cushings syndrome in the dog). Nord. Vet.-Med. 1972, 24, 113-122. 
Willet, L. B. \& R. E. Erb: Short term changes in plasma corticoids in dairy cattle. J. Animal Sci. 1972, 34, 103-111.

Wilson, R. B., L. J. Kleine, T. J. Clarke, E. C. Hendricks \& M. S. Grossman: Response of dogs to corticotropin measured by 17-hydroxycorticosteroid excretion. Amer. J. vet. Res. 1967, 28, 313322.

\section{SAMMANFATTNING}

Perifera plasmanivåer av corticosteroider hos normala Beagles och Greyhounds mätt med en snabb proteinbindarteknik.

En snabb proteinbindarteknik för bestämning av perifera plasmanivåer av corticosteroider hos hund har utvärderats och applicerats. Snabbindartekniken befanns ge en mindre överbestämning av cortisolnivån jämfört med en teknik som inkluderade rening av plasmaextraktet på Sephadex LH-20 kolonner. Hos Beagles och Greyhounds uppmättes en medelplasmanivå av corticosteroider till respektive 25,4 och 18,0 $\mathrm{ng} / \mathrm{ml}$. Ingen diurnal variation kunde konstateras. Efter intravenös dexametason injektion sjönk perifera corticosteroidnivån till ungefär 20 procent av nivån som uppmätts före injektionen. Intramuskulär ACTH injektion ökade corticosteroidnivån till nästan det tiodubbla 60 till 90 minuter efter injektionen. Den beskrivna och evaluerade metoden lämpar sig väl för diagnostik av binjurebarkssyndrom hos hund.

(Received September 3, 1973).

Reprints may be requested from: Lars-Eric Edqvist, Department of Clinical Biochemistry, Royal Veterinary College, S-104 05 Stockholm 50, Sweden. 